\author{
Cracow Indological Studies \\ Vol. XXIII, No. 1 (2021), pp. v-xviii \\ https://doi.org/ 10.12797/CIS.23.2021.01.00
}

\title{
Introduction: \\ History and Other Engagements with the Past in Modern South Asian Writing/s
}

While working on the present volume of Cracow Indological Studies, we were beset by an unprecedented, vicious onslaught of nature, something never seen in our lifetime-the coronavirus pandemic. It has affected, deeply and often tragically, many people all over the world, put strain on states and their health care systems, exposed yet again inadequacies of political leadership, highlighted social and economic disparities, and brought into open blaring inequalities within states and across geo-political regions. Undisputedly, the pandemic has reshaped our lives, but also provided us, at the critical moments, with outstanding examples of solidarity and kindness, and a promise of a light at the end of the tunnel. Historical and literary accounts of these challenging times are yet to come but we would like to dedicate this volume to the people of South Asia, especially those who have succumbed to the dreadful disease, with hope that those affected at present will recuperate, the region will soon recover, and so will its people.

The matter of recording history in South Asia remains at the centre of academic interest and the present volume, History and Other Engagements with the Past in Modern South Asian Writing/s, aims to reflect current debates with regard to the notion of narrating or writing history by recourse to certain specific formats, often disparate from 
what one usually understands to be history in the West. Originating in the colonial times, currently contested yet still widely held, prejudicial, Eurocentric theories claim that historiography, seen as a separate, source-based, critically unbiased method of analysing and writing history, is the only legitimate way of narrating the past and as such was never practiced in the "ahistorically minded" Indian subcontinent. This perception has been challenged, on the one hand, by those who have questioned the very notion of "objectivity" and "impartiality" of Western historiography and, on the other, by those who have been critical of the colonial and the postcolonial perspectives on Indian literary writings as unacceptable modes of representing the past. Hence, the postmodernist reflections on history-writing, starting from Hayden White's critical analysis of historical prose discourse, through narrativist theory of history, and the collective research and theorizations by Velcheru Narayana Rao, David Shulman and Sanjay Subrahmaniam in the context of South India (Rao et al. 2001), or the case studies of Braj historiography by Allison Busch (e.g. Busch 2015, 2014, 2012, 2005), have sensitized readers to view the multilingual literatures of South Asia as possibly embodying other, legitimate practice(s) of writing or telling the past. Recent scholarship on literary cultures of different periodswith a significant share of studies in early modern writings - has (re) discovered established models of narrating history that are grounded in literary genres. To quote Rao, Shulman and Subrahmaniam's reflections on early modern vernacular literature of South India: "It is as if the historical work has to be presented as a completed aesthetic whole, as part of an accepted literary genre with its own formal features, rather than an edifice that reveals its own scaffolding" (Rao et al. 2001: 96).

The present volume, first of the two-volume series, includes papers that examine certain developments in the modes of history writing as attested in the $19^{\text {th }}$ - $20^{\text {th }}$ - and $21^{\text {st }}$-century texts from South Asia. The contributions focus on texts that are "historical" not only within a narrow category of literary genres, but in the wider sense of literary practices for which appropriation of the past or engagements with it constitute a focal point or an important frame of reference. In view 
of the specific historical development of literary models of writing or telling history in India, we had invited research focused on the texts composed in various Indian languages. In the present volume, which will see its continuation later this year, we put together studies related to Malayalam, Punjabi, Urdu and Hindi literary traditions as well as accounts in English. The multilingualism of the area in focus here becomes a critical value as it allows us to see how the approach to history writing varies depending on the language it is produced in and the author/s positioning or their worldview.

Our aim was to bring together examples of academic investigations that focus on writings relevant to the processes of identity construction of specific communities today, where images of the past are shaped by the political agendas of the communities in question, or the widely understood patronage structures. Another point of interest that is reflected upon by the contributors are the ways in which the reception of writings that pertain to history-especially works that make an impact and generate change- -have the power to shape the narratives of the past in general.

We hope that present contributions will bring the reader closer to understanding the nature of history told through literature or, to be more specific, embedded within its textual contents, its forms, or yet other layers, such as the editing or publishing practices. Thus, for example, a reinstatement of a literary work within the canonical history of literature can be seen as a competing act of history making, often no less than creating a new narrative offering a counter-history. Such decisions on the part of the editors prove to be more than just involuntary historicizing measures. Through the inclusion of a novel perspective, the so edited work comes to embody different practices brought into play not only in the process of writing, but also in a widely understood circulation of literary texts.

The presented papers address different issues related to shaping the image of the past or rather the patterns of such shaping, often unique to South Asia. The texts under scrutiny, as well as reading practices associated with them, allow us to view at least part of a wide category 
of literature as "historical writings" in the sense that the latter can exert influence on power structures, society, and community. As the authors, but also the agents responsible for editing, publishing, and dissemination, set in motion specific patterns underwritten by their individual agendas, literary texts are often characterised by pragmatic aspects conventionally ascribed to historiography. All such agents may thus be seen as fulfilling various roles usually ascribed to historians, as they, too, act according to specific agendas or ideologies, just the way Michel de Certeau's historian does (e.g., de Certeau 1975). But the literature also tends to be, and usually is, more successful in going beyond the limitations of professional historiography that emerged in the West. One cannot deny that literary texts can be biased against or in favour of certain understanding of the past because of the ideological or personal perspective of the authors. However, they often provide a significantly wider, more nuanced picture of the past, and definitely present it in a more sensitive and inclusive way. For instance, a history of cultural rupture or devastation wreaked by the deaths or displacements of performing artists is something hardly to be grasped by the prosaics of historiography, but can be sensitively foregrounded through a work of poetry or an essay. Or, to take a different example, a work that intermingles fact and fantasy, even if it does not claim the right to be history, not only shapes the past, but makes one reflect on its sense and essence. Historical fiction has the power to present a variety of views on historical past, but primarily to include perspectives that usually tend to be or are ignored by the so called professional historical accounts.

With a paper titled, "Editorship and History Making: On Historicizing Modern Editions of Tirunilalmāla," by Cezary Galewicz, we take a deep dive into the editorial practices of modern Kerala and regional attempts at re-writing, or to be more precise, re-editing history in South Asia. The author argues that the specific editorial strategies employed by the two editors of the three modern editions of a $13^{\text {th }}$-century Malayalam text, Tirunilalmāla, "constitute competing acts of general history writing" and as such are deeply embedded in the debate on how to best represent Kerala's distinct cultural identity and regional history 
which is at the centre of the contemporary dispute on the specifically local ethos. Introducing a wide range of traditional Malayalam historical narratives - some of them partly inspired by rich Sanskrit tradition of sthalamāhātmya writings and some possibly developed under not yet explored influence of the Arab writings on history - the paper presents a detailed scrutiny of editorial interventions in three editions of the manuscript, i.e. two publications by M. M. Puruṣōttaman Nāyar (1981 and 2016), and one by R. C. Karippath (2006), all three brought out with the backing of the authority of two established universities, of Calicut and Kannur respectively. These editorial practices include division of the text into discrete sections, introduction of a set of paratexts absent from the manuscripts (titles and subtitles, introduction, notes, etc.) as well as emendations "that may look like intentional archaization (or retro-Tamilization/Dravidization)." Drawing on the notion of "enhanced autonomy of community-based literary speech" (Shulman 2016: 259) and the concept of a 'ghost title' seen as "an instrument of ascription for a culturally shared memory of a supposedly important text of great relevance to a community which happened to have lost memory of its actual title or/and author or finds itself in need of ascription," the author presents two hypotheses. Firstly, he claims that historicizing of the scrutinised editorial practices aims at establishing a missing scriptural link to ascertain continuum of a distinct ancient Keralite tradition of history writing; and secondly, that the studied practices attest to two distinct, regional affiliations connected to the issue of the transmission of the manuscripts and performative aspects of the text present in specific performative traditions of Kerala, i.e., one of the centre and the south of Kerala and the other of the north. According to Galewicz, these editorial interventions seem to be contesting each other as they simultaneously point to a single coherent Keralite identity and its multiple, more localised versions.

It is a religious-cum-cultural identity that is the focal point of the writings of Shahid Ahmad Dehlvi (1906-1967), analysed by Richard David Williams in "The $r \overline{a g}$ that Burned Down Delhi: Music and Memory Between 1857 and 1947." The body of essays under study here, two in 
Urdu - delving into the nostalgic past of the now lost Indo-Muslim culture - and one in English - addressing the continuity of Indo-Islamicate musical traditions in Pakistan — present, as argued by Williams, glimpses of two different ways of narrating history since they were intended for two different readerships, i.e., the community of Urdu readers familiar with the cannon of its literature and those outside it. The Urdu essays speak of the decline of the musical and performing arts in the postindependence Delhi, once one of the glorious cultural centres of the Mughal empire with its extended network of noble patronage where artists, instrumentalists, singers, and dancers flourished under the benefaction of connoisseur circles. However, the historical traumas of 1857 and 1947, or the Indian Rebellion and the Partition of the British India, subsequently led to the decline of Delhi's Indo-Islamicate community and its musical culture, which Dehlvi bewails. Dehlvi, whose name, a demonym, suggests he is from Delhi, writes his essays away from the city where he was born, in his new home in Karachi, Pakistan, his re-location brought about by the Partition. Indeed, Dehlvi combines the nostalgic images of musical and dance traditions with the glimpses of horrors of the 1947 violence, hence, in Williams' parlance, presents "a meditation on cultural loss and personal trauma embedded within his discussion of music." Throughout Dehlvi's Urdu essays the tales of musical celebrations and dance soirées intersect with recollections of the disruption of 1857 and 1947, two seminal time-junctures that mark turning points in the history of Muslims in the Indian subcontinent. The consequent, final, post-Partition decline in the status of musicians and dancers, whose livelihoods were affected either way — by staying in India or migrating to Pakistan-inevitably disturbed the musical and dance heritage. While giving an account of a large musical gathering, of 200 or so musicians, a gathering that took place a couple of months before the Partition, Dehlvi evokes a similar musical event in 1927, famously described by another literati 'from Delhi,' Mirza Farhatullah Baig Dehalvi (1883-1948). Williams expounds how Shahid Ahmad Dehlvi, in writing his history of the Indo-Islamicate culture of Delhi, not only frames his account by recourse to an already available template but 
further draws on the earlier nostalgia-imbued literary tradition of Urdu through rich intertextual references. But in the English essay, intended originally for a foreign audience and readers unfamiliar with Urdu and its milieu, Dehlvi sketches a historical outline of the development of the Indo-Islamicate music by foregoing the nostalgia and taking an optimistic view projected towards the future. He imagines how in the new, post-Partition geo-political setup the musical heritage of North India would be enriched by the folk tunes of Bengal and Sindh, historical regions now a part of the new Muslim state of Pakistan. However, with the benefit of hindsight — and in view of the 1971 war and Bangladesh's proclamation of independence-Dehlvi's buoyant projections sound bitter, though the author, who died in 1967, did not live to see this painful turn of events. Williams reasons that a systematic comparison of the three essays "demonstrates how the same author could construct different historical arguments on the basis of music, subject to his immediate priorities and readerships."

The in-depth analysis of the development of concepts and theories of Benoy Kumar Sarkar (1887-1949), an influential Bengali social scientist and revolutionary nationalist, is at the core of Rohit Wanchoo's paper, "Scholar and Spokesman: Benoy Sarkar on the West, Religion, Nationalism and Internationalism." Wanchoo recapitalizes Sarkar's criticism of orientalist constructions of the East and the West, as well as his understanding of Buddhism and Hinduism, nationalism and internationalism. Sarkar is a controversial public figure, mainly due to his disputed relationship to fascism; some scholars even interpret his writings as an open support of that ideology while others see him as aligned with the right-wing conservatism. Wanchoo claims that it is Sarkar's interpretation of history of the East and the West, as well as his studies in comparative anthropology and psychology, that lead him to the conclusion regarding essential similarities between these two, otherwise dichotomously perceived regions. Wanchoo writes, "Sarkar's project of writing a history without Eurocentric biases and his hopes for mankind must not be eclipsed by the digressions and deviations in his long intellectual journey." 
The next four papers are dedicated to Hindi literature and its specific engagements with the past, starting from an early example of Hindi prose (paper by Justyna Wiśniewska-Singh), going to two acclaimed Hindi authors of the past (papers by Justyna Kurowska and Rosine-Alice Vuille), and ending with the analysis of a short story by one of the most critically acclaimed contemporary prosaists (paper by Veronica Ghirardi). Operating within diverse theoretical frameworks, the studies propose different ways of exploring distinctive works of Hindi literature-as polemical voices in a wider narrative of identity formation; as nuanced, collective or/and individualized accounts of certain traumatic events of India's past; and as some literary reflections on meta-narratives of colonial and post-colonial history.

Going back to one of the earliest examples of Hindi novel, viewed as an exercise in the narrative of nation building, Wiśniewska-Singh's “"Helpless Indian:' The Sacred Cow as the Symbol of Hindu-Muslim Unity in a Late Nineteenth-Century Hindi Novel" discusses Nissahāy hindū of 1881 (published in 1890) by Rādhākrșnadās (1865-1899) and its treatment of Muslim protagonists' engagement in the cow protection movement as an image of communal harmony. Its subject-especially when viewed against the current political background of the aggressive right-wing agitation for cow protection that has pushed for legal acts banning cow slaughter in most of Indian states, and of the barely disguised animosity of the Hindutva towards Indian Muslims-is of specific relevance to modern Hindi readership and to studies of discourses on nationalism in Hindi public sphere. The paper explores the correlation between the novel and an earlier speech of a highly influential Hindi intellectual and literati, Bhāratendu Hariścandra, incidentally, a cousin of Rādhākrș̣nadās, the novel's author. In his seminal speech, Hariścandra calls for national unity of different religious communities. Investigating a somewhat ambiguous approach to Muslims in Hariścandra's writings and Rādhākrșṇadās's novel which yet again revisit the conflict between loyalty towards religious and communal identities and loyalty towards newly emerging and ongoing formation of a national identity (Chandra 1984), Wiśniewska-Singh scrutinises possible connotations of 
the Hindi word hind $\bar{u}$, used in the sense of an inclusive 'Indian' and not exclusive 'Hindu,' hence providing a different reading of what seemed to be a self-explanatory title of the novel.

A temporal shift from the beginnings of Hindi novel to one of the examples of its mature form is marked by a paper of Justyna Kurowska titled "How Real is Hunger? Stories of a Disaster and Amrtlāl Nāgar's Bhükh." It examines a novel by an accomplished Hindi writer, Amrtlāl Nāgar (1916-1990), and its coverage of the Bengal famine of 1943, caused not by a natural disaster but the failure of the British policy; a famine that resulted in the death of at least one, and probably up to three million people. The novel, based both on the firsthand experience of the author who was a witness to this men-induced calamity and the notes made by him between 1944 and 1946, the same further supplemented by accounts collected from family members and the survivors, paints a dehumanised portrayal of starving people against the backdrop of India under the colonial rule, the society divided by caste and class and corrupted by toxic power relations. The paper voices criticism of the novel for its lack of "in-depth analysis or historical insights," "the aesthetic admixture of didacticism, naturalism, and behaviourism, with melodramatic style, and idealised happy ending" and "the absence of in-depth criticism of the social order." The specific metaphorical vocabulary of Hindi that refers to the famine through images of the mythological catastrophe or "the end of the world" is reflected both in the original title, Mahāka $\bar{a}$, later changed to a more generic $B h \bar{u} k h$, and the descriptions of the apocalyptic scenes taking place. The novel strongly evokes other narratives of survival focalised from a perspective of those famished whose existence is reduced to catering to their basic needs, like, for example, the Noble prize winner, Knut Hamsun's novel Hunger (1890), with which, one could speculate, the well-read Nāgar would have been probably familiar. However, finding Nāgar's novelistic portrayal of the Bengal famine shallow and wanting, Kurowska concludes, "the historical vision Nāgar lays in front of his readers, presented as his own history, indeed proves to be a selfcentred, upper caste, and conventional representation, apocalyptic but 
detached from an average 'hunger' experience based on lived starvation and not on 'experimenting' with not eating."

One of the greatest achievements of Hindi prose is discussed in a paper of Rosine-Alice Vuille titled "The Living Tree: Krșṇā Sobtî's Pre-Partition Punjab and the "Other History" and focused on Zindagīnāmā (1979) for which Sobtī received Sahitya Akademi award in 1980. The novel paints a broad canvas of the pre-Partition Punjab with its numerous communities defined by their religion, caste and class, their different ways of life marked by specific customs and ethos, and their subjective re-readings of the past. Interestingly, Vuille elicits Sobtî's own theorisation of history, or her focus on "other history" (dusrā itihās)—a lore of collective accounts, like oral folk tales, songs, and family stories - as essential to identity formation and, hence, essential to her writing. According to Vuille, Sobtî's notion of "other history," as seen in her novels and in her belle-lettres, is akin to the concept of "mnemohistory" developed by Jan Assmann ("concerned not with the past as such, but only with the past as it is remembered," Assmann 1998: 8-9). Vuille writes, "Sobtî's approach to history writing reflects the idea that the history lived and remembered (and later transmitted through community tales, folklore, and in other ways) has a greater impact on the perception of the past-and, as a due consequence, on identity constructions - than a more factual history, from which it can also markedly differ."

The final study on Hindi literature's rereading of the past brings us again to authorial reflections on the nature of historiography within post-colonial and post-modern framework. Ghirardi, in "The Presence of the Past: History and Imagination in Uday Prakāś's Vāren hesțings $k \bar{a} s \tilde{\tilde{a}} d$," examines a widely discussed 1996 short story by a critically acclaimed Hindi writer. Her detailed analysis enriches the present volume, as it probes into a wide spectrum of textual—and visual—interventions in which Prakāś engages with the debate on Indian colonial history in the post-colonial and the post-modern context. Prakāś, by sensitizing his audience to the dominant narratives of history embedded in power structures, plants a seed of doubt in reader's mind and unveils 
a fictitious but plausible - yet not supported by the so called 'hard' historical evidence - tale from Warren Hastings's life (perceived by Ghirardi as "historiographic metafiction," Hutcheon 1989 and 2004). The short story seems to play "hide-and-seek" with historiography as a construct that glorifies colonizers and hence decides to bring in voices of "others" otherwise left unnamed and unknown on the margins of meta-history. To that end Prakāś comes up with reinterpretations of the so called 'records' of the period-like reproductions of two contemporary paintings that are appended with the text. Referring to the title character, the Indian bull that was gifted to Hastings and that went mad when taken by him to England, Prakāś ironically builds a fastforward account of India's history from Mohenjo Daro, to Arias, and to the First War of Independence (or the Indian Mutiny - the denomination of choice yet again reflecting the competing narratives of the past). His blending of fiction and facts, and his self-reflexive comments embedded in the text, seem to sensitize readers to historiography that remains, after all, a narrative, only one of the many possible, to quote Prakāśs provocative statement in Ghirardi's translation "every līla and every māya is as true as history itself."

Sandip Kaur's Punjabi autobiography (2008), the most contemporary text of those in focus in the present volume, is investigated by Maria Puri in "Female, Sikh, Militant...: The Story of the Self as History in Sandip Kaur's Autobiography Bikhrā Paĩdā." The departure point for the paper is contemporaneous with the ongoing demonstrations against the new agriculture reforms of 2020 and public resurfacing of the term "Khalistani" seen as a term of abuse imbued with seditious undertones by those in power but crucial to understanding Punjabi identity politics, in particular during the Punjab insurgency, and hence relevant to the auto narrative under study. The core of the analyzed text pertains to the said insurgency period but covers also Kaur's childhood and youth before her militancy and her charitable work after the militancy and incarceration. The genre of autobiography itself, straddled between fact and fiction, lived life and its narrative embodiment, is per se engaged with the retelling of history from a personal perspective, particularly 
when such a life, and hence its account, are entangled in highly controversial and disputable acts of violence. Puri, locating the text at the intersection of Kaur's personal story and collective tales of Sikh cultural ethos, in particular its enhancement of martyrdom, scrutinizes exhaustively the content and organization of the main body of text and its rich paratextual materials. She also positions it within a cohort of life writings by militant women from across the world bringing out the feminist lens. Puri argues that Kaur pens "a counter-narrative to 'the official state memories of 1984 [which] are replete with omissions' (Devgan 2013: 207)," which serves “as a personal or communal metacommentary but also a historian's testimonial treasure-throve and an example of historical writing per se" that gives "voice and space" to women combatants and "inserts them into history," "though not necessarily yet giving them a place in the history text-books."

When zooming out to look for a common denominator for the studies offered in this volume, one might first come to a rather obvious conclusion that the patterns providing grid to the texts shaping the past today are underwritten by specific agendas. However, we believe that one of the greatest empirical values of this volume will be its ability to widen the reader's awareness of the multiple dimensions that one may discover in the notion of agenda, as used in the context of writing about the past. The literary texts, or literary practices, highlighted by the contributors to this volume, undoubtedly share common traits with historiography of Western origins. These are traits that allow one to treat many South Asian texts or practices as culturally conditioned equivalents of history in its comparatively narrow Western understanding. The texts and practices under consideration have equal power to perform certain crucial functions ascribed usually to a more conventional history-writing, originating in the West or corresponding to our idiosyncratic, Western understanding of history. Thus, manifold ways of telling, writing, or shaping the past by engaging with literary practices in South Asia, as the collected studies convince us, potentially impact the power structures, societies, communities, etc. Most of those texts and practices, when presenting the past, offer a plethora of complex, 
nuanced, deeply sensitive images. Not forgetting about the possibility of bias that is often to be found in such (or any) "history," one may often consider the unavoidable distortions within such images as more palpable or perceptible - thus probably also more conscientious and sincere-than in case of many so called professional historical accounts.

We express our gratitude to the contributing scholars for taking interest in our idea for this (and the subsequent) volume, and for their enthusiastic response in the form of eight insightful papers that we can hereby offer to the readers.

Piotr Borek (D)

(Jagiellonian University, Kraków, Poland) piotr.borek@uj.edu.pl

Monika Browarczyk (D) (Adam Mickiewicz University, Poznań, Poland) monikabr@amu.edu.pl

\section{References}

Assmann, J. 2011. Cultural Memory and Early Civilization: Writing, Remembrance, and Political Imagination. Cambridge: Cambridge University Press. https://doi.org/10.1017/CBO9780511996306.

Busch, A. 2015. Listening for the Context: Tuning in to the Reception of Riti Poetry. In: F. Orsini and K. Butler Schofield (eds). Tellings and Texts: Music, Literature and Performance in North India. Cambridge: Open Book Publishers: 249-282. https://doi.org/10.11647/OBP.0062.09.

Busch, A. 2014. The Classical Past in the Mughal Present: The Brajbhasha Rìti Tradition. In: Y. Bronner, D. Shulman and G. Tubb (eds). Toward a History of Kāvya Literature. New Delhi: Oxford University Press: 648-690. 
Busch, A. 2012. Portrait of a Raja in a Badshah's World: Amrit Rai's Biography of Man Singh (1585). In: Journal of the Economic and Social History of the Orient, 55: 287-328. https://doi.org/10.1163/15685209-12341237.

Busch, A. 2005. Literary Responses to the Mughal Imperium: The Historical Poems of Keśavdās. In: South Asia Research, 25(1): 31-54. https://doi.org/ $10.1177 / 0262728005051606$.

de Certeau, M. 1975. L'écriture de l'histoire. Paris: Gallimard.

Devgan, S. 2013. From the 'crevices in dominant memories:' Virtual Commemoration and the 1984 Anti-Sikh Violence. In: Identities: Global Studies in Culture and Power 20(3): 207-233. https://doi.org/10.1080/1070289X. 2013.771579.

Hutcheon, L. 1989. Historiographic Metafiction: Parody and the Intertextuality of History. In: P. O'Donnell and R. Con Davis (eds.). Intertextuality and Contemporary American Fiction. Baltimore: Johns Hopkins University Press: $3-32$.

Hutcheon, L. 2004. A Poetics of Postmodernism: History, Theory, Fiction. London-New York: Routledge. https://doi.org/10.4324/9780203358856.

Rao V. N., D. Shulman and S. Subrahmanyam. 2011. Textures of Time: Writing History in South India 1600-1800. Delhi: Permanent Black.

Shulman, D. 2016. Tamil. A Biography. Cambridge, Mass.-London: The Belknap Press of Harvard University Press. 